\title{
GEOLOGIC MAP OF THE UPPER CHENA RIVER AREA, EASTERN INTERIOR ALASKA
}

by

T.E. Smith, M.S. Robinson, F.R. Weber, C.W. Waythomas, and R.R. Reifenstuhl

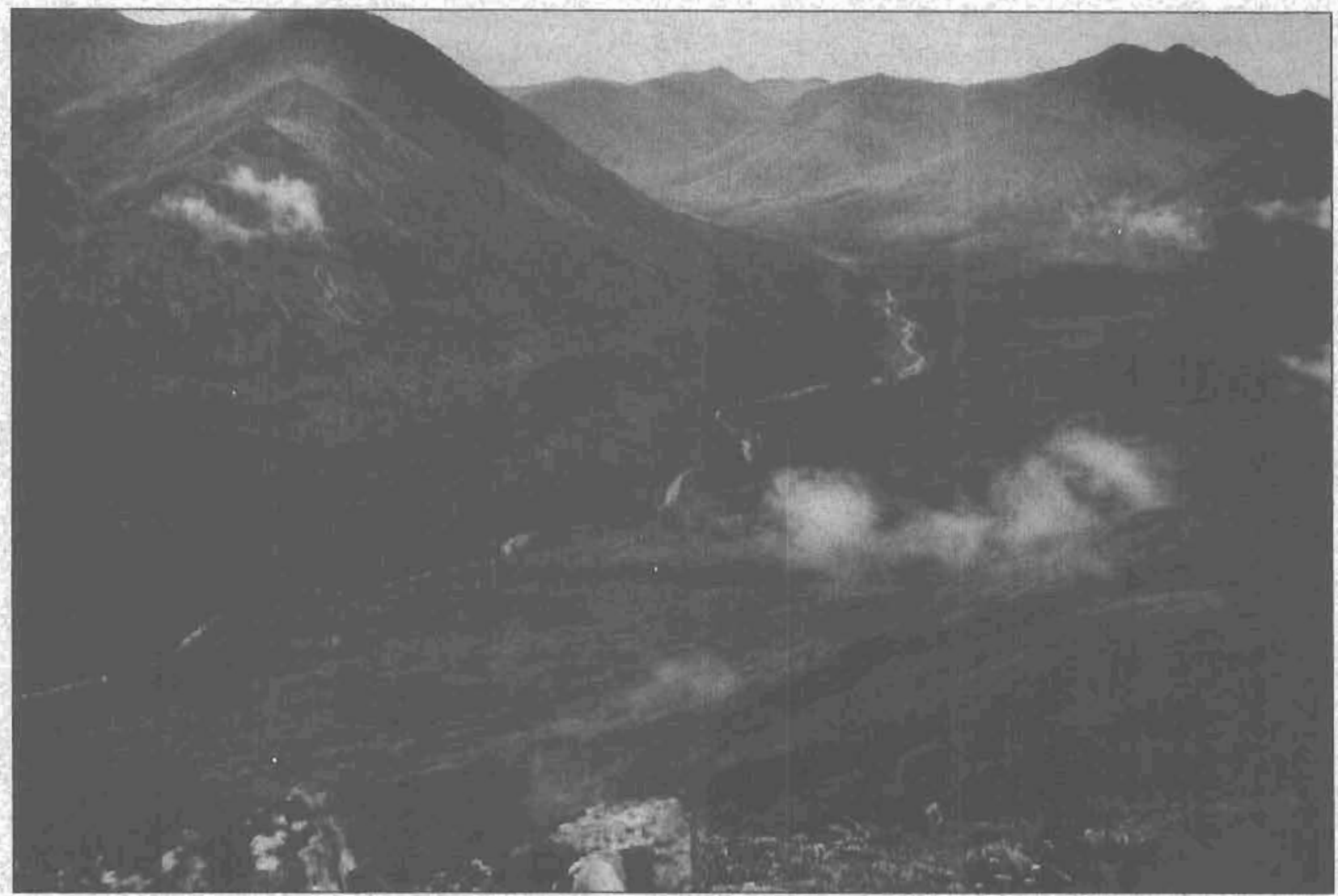

Professional Report 115

Fall 1994

Published by

State of Alaska

Department of Natural Resources

DIVISION OF GEOLOGICAL \& GEOPHYSICAL SURVEYS

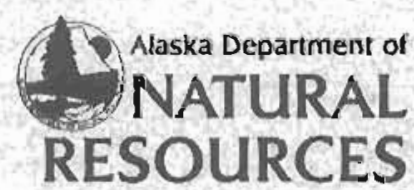




\section{GEOLOGIC MAP OF THE UPPER CHENA RIVER AREA, EASTERN INTERIOR ALASKA}

by

T.E. Smith, M.S. Robinson, F.R. Weber, C.W. Waythomas, and R.R, Reifenstuhl 


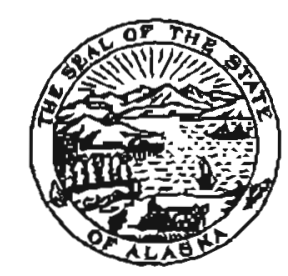

STATE OF ALASKA

Walter J. Hickel, Governor

DEPARTMENT OF NATURAL RESOURCES

Harry A. Noab, Commissioner

DIVISION OF GEOLOGICAL \& GEOPHYSICAL SURVEYS

Thomas E. Smith, State Geologist

Division of Geological \& Geophysical Surveys publications may be inspected at the following locations. Address mail orders to the Fairbanks office.
Alaska Division of Geological
\& Geophysical Surveys
794 University Avenue, Suite 200
Fairbaniss, Alaska 99709-3645
University of Alaska Anchorage Library 3211 Providence Drive
Anchorage, Alaska 99508

Elmer E. Rasmuson Library

University of Alaska Fairbanks

Alaska Resource Library

$222 \mathrm{~W}$. 7th Avenue

Fairbanks, Alaska 99775-1005

Anchorage, Alaska 99513-7589

\begin{abstract}
Alaska State Library
State Office Building, 8th Floor 333 Willoughby Avenue

Juneau, Alaska 9981 1-0571
\end{abstract}

This publication released by the Division of Geological \& Geophysical Surveys, was produced and printed in Fairbanks, Alaska by Graphic North Printing Company, at a cost of $\$ 8.50$ per copy. Publication is required by Alaska Statute 41, "to determine the potential of Alaskan land for production of metals, minerals, fuels, and geothermal resources; the location and supplies of groundwater and construction materials; the potential geologic hazards to buildings, roads, bridges, and other installations and structures; and shall conduct such other surveys and investigations as will advance knowledge of the geology of Alaska." 


\section{CONTENTS}

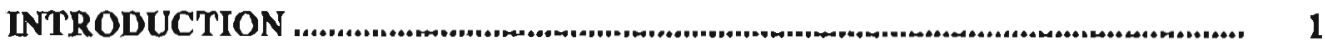

Background ...............................................................................................

Geologic setting .............................................................................................

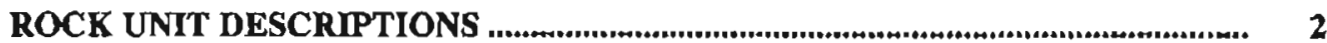

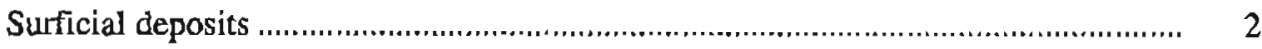

Bedrock units ................................................................................................ 3

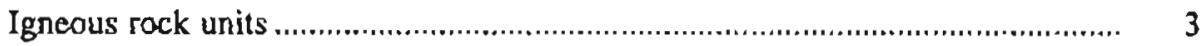

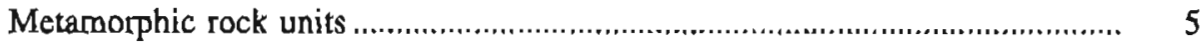

Totalanika schist ............................................................................ 5

Blackshell and Dan Creek units ................................................................ 6

Chena River sequence........................................................................ 7

Quartzite-dominant basement units ..................................................... 9

West Point igneous/metamorphic complex ........................................... 10

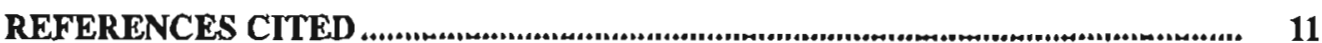

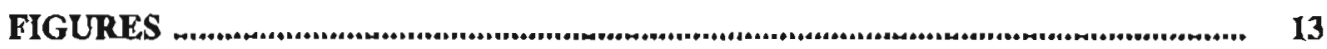

Figure 1A. Streckheisen plot of igneous rock classification .................................. 14

Figure 1B. Plot of A/CNK ratio for igneous rocks ................................................. 14

Figure 2A. Plot of $\mathrm{Na}_{2} \mathrm{O}$ versus $\mathrm{K}_{2} \mathrm{O}$ for igneous rocks ........................................... 14

Figure 2B. Plot of $\mathrm{Pe}_{2} \mathrm{O}_{3}+\mathrm{FeO}$ for igneous rocks .............................................. 14

Figure 3. Molar $\mathrm{AV}(0.5 \mathrm{Ca}+\mathrm{Na}+\mathrm{K})$ versus differentiation index plot for igneous rocks ........................................................................................ 14

Figure 4. Plot of uranium-lead model age for zircon from rhyolite of the Blackshell unit (Pzbr), map location $J$

Figure 5. Plot of uranium-lead model age for zircon from orthogneiss of the West Point complex (pCwo), map location V ................................................ 15

Figure 6. Uranium-lead concordia plot of zircon data from augen gneiss of the Chena River sequence (Pzra), in eastern map area, map location 5................. 15

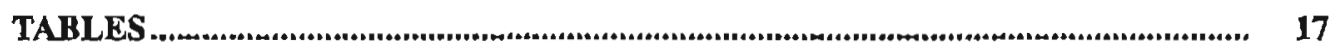

Table 1. Potassium-argon ages of igneous and metamorphic rocks in the Upper Chena River region

Table 2. Whole-rock major-oxide analyses and CIPW normative mineralogy of igneous rocks in the southcentral Circle and northcentral Big Delta Quadrangles

SHEET in pocket

Geologic map of the Upper Chena River area, eastem interior AJaska 


\title{
GEOLOGIC MAP OF THE UPPER CHENA RIVER AREA, EASTERN INTERIOR ALASKA
}

\author{
by \\ T.E. Smith, ${ }^{1}$ M.S. Robinson, ${ }^{1}$ F.R. Weber, ${ }^{2}$ C.W. Waythomas, ${ }^{2}$ and R.R. Reifenstuhl ${ }^{1}$
}

\section{INTRODUCTION}

\section{BACKGROUND}

Geologic studies of the upper Chena River area were undertaken in 1983 as part of the Interior Mining District Evaluation Program, a series of projects designed to develop new information on known mineral districts in interior Alaska. The evaluation program was conceived by economic geologists in the Division of Geological \& Geophysical Surveys (DGGS) and the Mineral Industry Research Laboratory (MIRL) of the University of Alaska Fairbanks. The Alaska legislature provided funding for the studies through capital and operating budget appropriations. During the three-year course of the program, geologists examined four districts that have contributed significantly to historical gold production in Alaska's Interios-Fairbanks, Livengood, Richardson, and upper Chena River, Personnel staffing the projects came mainly from DGGS and MIRL, with participation in selected areas by members of the U.S. Geological Survey, the U.S. Bureau of Mines, and the Geophysical Institute, University of Alaska Fairbanks.

The authors chose to study the upper Chena River district to better understand (1) the source of placer gold resources near Van Curler's Bar, (2) the nature and production potential of tungsten-bearing skams in the eastern raparea, and (3) a proposed route of a transportation corridor through the area.

\section{GEOLOGIC SETTING}

The upper Chena River map area is located in the nortbcentral part of the Yukon-Tanana upland (YTU), a region underlain primarily by crystalline rocks of the Yukon-Tanana metamorphic complex (YTMC). The oldest rocks in the complex are schists and quarzites of the formation formerly known as the Birch Creek Schist (Mertie, 1937). Crystalline metamorphic rocks of the YTMC range from greenschist and epidote-amphibolite facies to garnet-amphibolite facies. In the map area, rocks of the basement complex have been intruded by orthogneisses and yield $\mathrm{U}-\mathrm{Pb}$ model ages of $671 \pm 34$ million years.
The Yukon-Tanana upland (YTU) is bounded on the north by the Tintina fault and on the south by the Denali fault. Both of these strike-slip faults have large-scale, right-lateral displacements (200-300 miles) that bring crustal blocks of contrasting geology into juxtaposition. The oldest structural features in the YTU trend northwest; however, superimposed northeast structures are dominant in the northwestern part of the block. The northeast-trending folds transect the older structural grain and appear to have formed about $90-120 \mathrm{Ma}$.

Geologic mapping by Weber and others (1978) in the Big Delta Quadrangle has documented that the YTU is transected by several northeast-trending faults. These faults include Shaw Creek and Mansfield Creek faults, which have left-lateral offsets of up to a few miles. PIutonic rocks ranging in composition from quartz diorite to granite intrude the YTU at many localities. Some of these bodies, including the Charley River and Mt. Harper plutons, are of batholithic dimension and encompass several hundred square kilometers. The intrusives range in age from Precambrian to Tertiary.

Bedrock exposed in the upper Chena River rnap area includes several metamorphosed stratigraphic units. The lowermost sequence, the West Point complex, consists of upper-amphibolite facies metamorphic rocks that, prior to metamorphism, were pervasively intruded by feisic to intermediate igneous rocks. Boundaries of the West Point complex grade into the overlying metamorphic or stratigraphic packages. The quartzite-dominant basement unit consists of quartzite, pelitic schist, and minor marble and is believed to correlate with rocks of the Fairbanks Schist unit, the lowermost stratigraphic unit exposed in the Fairbanks mining district to the southwest (Robinson and others, 1990). The Chena River sequence is stratigraphically above the quartzite-dominant basement unit in the upper Chena River region. This lithostratigraphic unit is best exposed in a broad shallowplunging regional synform in the eastern part of the map area. Lithologies of the Chena River sequence contrast markedly with rocks of the underlying quartzite-dominant unit. Rock types include metavolcanic rocks,

\footnotetext{
Present affiliations:

'Alaska Division of Geological \& Geophysical Surveys

¿U.S. Geological Survey
} 
diopside-rich quartzite, thick marble and calcschists, augen gneisses, and pelitic schist. The Chena River sequence in the map area correlates with rocks of the Chena River sequence in the Fairbanks mining district (Robinson and others, 1990).

Calcschist and calcphyllite of the Dan Creek unit, which is stratigraphically above the Chena River sequence, grade upward to black quartzite and phyllite of the Blackshell unit. The Dan Creek and Blackshell units are best exposed in the low hills south of the Middle Fork of the Chena River in the westcentral part of the map area. These units represent a iransition upsection both in composition and metamorphic grade. Rocks of the Blackshell unit probably correlate with the Keevy Peak Formation in the Alaska Range to the south. Totatlanika Schist, the uppermost stratigraphic unit exposed in the upper Chena River area, consists of tan and green phyllites and semischists, phyllitic quartz arenite, and thin-bedded marble and calcschist. In the map area, rocks of the Totatlanika Schist are in thrust contact with the underlying Blackshell lithologies. Totatlanika Schist of the upper Chena River area correlates with Totatlanika Schist of the Alaska Range (Wahrhaftig, $1970 \mathrm{a}-\mathrm{h}$ ).

\section{ROCK UNIT DESCRIPTIONS}

\section{SURFICIAL DEPOSITS}

Qd Glacigenic deposits, undifferentiated-Includes all varieties of till, outwash, and minor colluviated drift or other diamicton. Consists of poorly sorted, generally nonstratified, gravelly sediment, with a sand and silt matrix. Age unknown

Qd5 Glacial drift-Heterogeneous glacial diamicton and minor outwash deposits. Consists of nonstratified, poorly to moderately sorted sandy gravel with varying amounts of silk, clay, and boulders. Deposits are associated with valley-head moraines in cirques. Least extensive of all drift units recognized. Age uncertain, but probably late Pleistocene to Holocene

Qd4 Glacial drift-Heterogeneous glacial diamicton associated with unmodified knob-and-kettle moraine. Consists of till and minor outwash. Sediment ranges from poorly sorted bouldery gravel in a silty matrix to well-sorted sandy gravel. Less extensive than Qd3 but more extensive than Qd5. Age uncertain, but probably late Pleistocene
Qd3 Glacial drift-Heterogeneous glacial diamicton in moraines and minor glaciofluvial deposits. Drift bodies and moraines are partially subdued and locally exhibit hummocky, ice-stagnation topography, Narural exposures and hand-dug pits reveal poorly sorted silty gravel and moderately wellsorted, sandy gravel with variable amounts of boulders and cobbles. Less extensive than Qd2 but more extensjve than Qd4. Age uncertain, but probably middle to late Pleistocene

Qd2 Glacial drift-Heterogeneous glacial diamicton associated with subdued moraine and outwash deposits. Usually present as isolated remnants on valley floors inside limits of Qd1. Consists of poorly sorted to moderately well sorted silty gravel with variable amounts of silt, sand, and boulders. Age uncertain, but probably middle Pleistocene. Morainal crests generally wind deflated and litsered with highly weathered and pitted erratic boulders

Qd1 Glacial drift-Heterogeneous glacial diamicton, present in very subdued drift bodies that partially cap ridges and knolls. Includes varying amounts of till, outwash, colluviated drift, and gelifluction deposits. Consists of poorly sorted, silty gravel. Locally frozen below depths of about 3 feet. Age uncertain but is probably early to middle Pleistocene. Qd l is the most extensive drift recognized. Generally not associated with recognizable morainal topography. Contains exhumed, highly weathered erratic boulders

Qdo Glacifuvial outwash, undifferentiatedClast-supported cobble and small-boulder gravel. Generally exhibits good primary stratification, is well sorted and contains rounded to subrounded clasts. Associated with high-level fluvial terraces. Locally capped by up 107 feet of frozen eolian silt. Age uncertain. May have placer potential
Qd05 Qdo4

Qdo3

Qdo2 Qdo1 Glacifluvial outwash-Moderately to wellsorted, clast-supported, cobble and smallboulder gravel with minor silt and sand. Deposits form fluvial terraces that are related to glacial drift units by morphologic relations. Estimated age same as associated drift units. Outwash terraces are usually mantled by several feet of frozen eolian silt and sand. May have placer potential 
Qrg Rock-glacier deposits-Lobate or tongueshaped accumulations of bouldery talus and scree exhibiting evidence of downslope movement. Often characterized by multiple crescentic ridges that are parallel to but upslope of deposit teminus

Qea Alluvium and colluvium, undifferentiated-Interstratified alluvium and colluvium that include mudflows, debris flows, snow and avalanche fans, and colluvial deposits emanating from steep channels and gullies. Consists of poorly stratified, nonsorted, gravelly to silty sediment

Qa Undifferentiated alluvium-Moderately to well-sorted cobble and pebble gravel, sand and silt. Undifferentiated with respect to age. Generally forms low terraces above active flood plains. May have placer potential

Qal Flood-plain allurium-Moderately to wellsorted cobble and pebble gravel, sand, and overbank silt on flood plains or in active stream channels. May contain organic detritus as discrete beds or layers. May be mantled by colluvial deposits along flood plain margins. Coarse-grained alluvium may contain placer deposits

Qaf Alluvial fan deposits, undifferentiatedModerately sorted, crudely stratified, cobble and pebble gravel with minor sand and silt. Forms cone- or fan-shaped alluvial deposits along the base of mountain fronts and valley slopes. Usually clast-supported and may contain lenses or wedges of angutar colluvial gravel

Qc Colīuvial deposits, undifferentiatedAngular, poorly sorted, nonstratified gravel with varying amounts of sand, silt, and clay. Common on slopes less than $45^{\circ}$, where these deposits form blanketing mantles. May include gelifluction deposits and minor alluvium. Deposits usually include permafrost

Qcd Colluvial drtft-Reworked surfaces of moraines and other glacial deposits. Consists mainly of retransported glacial diamicton and outwash. Contains varying amounts of sand, silt, and boulders

Qcg Gelifluction deposits-Poorly sorted to angujar gravel with varying amounts of sand, silt, and clay. Forms lobate sheets or individual tongues of reworked sediments on underlying deposits that are prone to seasonal freezing and thawing. Well developed in older, subdued glacial drift

Qct Talus fans and aprons, undifferentiatedCoarse, blocky, rock rubble along the base of steep mountain slopes. Associated with cone- or fan-shaped talus landforms that often coalesce, forming talus aprons. Includes avalanche boulder tongues, boulder trains, and may include debris flow deposits

Qcc Slope talus - Coarse, blocky, rock rubble that forms a blanketing layer of talus and scree on mountsin slopes. Includes stone stripes. gelifluction deposits, and rock-glacier talus

Qcf Fine-grained colluvium-Retransported silt, locally interbedded with sand and gravel Mainly on lower hillslopes and valley bottoms

Qcl Landslide deposits-Unconsolidated sediments disturbed by slope failure in the form of slumps or slides. Deposits usually exhibit hummocky surface morphology and tipped, uprooted, and leaning trees and vegetation

Qlp Peat, peaty silt, and fen deposits-Accumulations of peat in bogs and swamps. May be interstratified with loess or alluvium. Usually found in low-lying areas: deposits are up to several meters thick

Qht Placer taillings-Irregular piles and mounds of mining waste and overburden. Consists mainly of gravel, sand, and minor silt

\section{BEDROCK UNITS}

\section{IGNEOUS ROCK UNITS}

Intrusive igneous rocks of the upper Chena River area are mostly multiphase bodies consisting of (1) biotite or hornblende-biotite granite and hornblende granodiorite in the northem and central parts of the map area and (2) intrusive bodies dominated by biotite or homblende-biotite granodiorite in the southern part of the area. Figure 1A illustrates the composition of the intrusives that plot wholly within the granodiorite and granite fields of Streckeisen and Le Maitre (1979). Field and petrochemical evidence indicates a mesozonal level of emplacement. Crosscutting field relationships and $\mathrm{K}-\mathrm{Ar}$ age determirations (table 1) indicate that the plutons that are dominantly granodiorite in composition are between 91.6 and 96.3 $\mathrm{Ma}$, whereas granite-dominant intrusives are between 64.4 and $77.5 \mathrm{Ma}$. There is a similar composition versus age relationship in the Fairbanks mining district to the southwest (Robinson and others, 1990). 
Overall, the intrusive suite of the upper Chena River area is weakly peraluminous (table 2, fig. IB) and is part of the calc-alkalic peraluminous series (fig. IB), Figure 2A illustrates the composition of the suite that plots wholly within the I-type intrusive field of White and Chappel (1983), and also plots within the oxidized field on a $\mathrm{Fe}_{2} \mathrm{O}_{3}+\mathrm{FeO}$ versus $\mathrm{SiO}_{2}$ diagram (fig. $2 \mathrm{~B}$ ). Newberry and others (1990) included chemical analyses of samples from selected intrusive bodies in the upper Chena River area in their regional study of the igneous rocks throughout the Yukon Tanana region. The analyses demonstrated that the upper Chena igneous suite is highly fractionated as shown by a general decrease in the peraluminous index with increasing differentiation index (fig. 3).

In another study of gold favorability of nomporphyry type intrusives in the Big Delta Quadrangle, Solie and others (1990) concluded that rocks of granodioritic composition are the most favorable igneous rock type in the Big Delta Quadrangle for associated nonporphyry gold type deposits. Their discriminant analyses indicated that units $\mathrm{Kgd} 1, \mathrm{Kgd2}$, and Mzwg have excellent favorability for associated nonporphyry gold deposits and that unit $\mathrm{Kgr} 5$ bas moderate favorability. Units $\mathrm{Kgr} 1, \mathrm{Kgr}$, $\mathrm{Kgr} 3$, and $\mathrm{Kgr} 4$ are less favorable for associated nonporphyry type gold deposits.

Tgr Granite-Medium light-gray to gray, fine- to coarse-grained, nonporphyritic, hypidiomorphic granular, homblende-biotite granite. Estimated modal composition: 40 percent microcline, 25 percent plagioclase, 15 percent quartz, 10 percent biotile. 5-10 percent homblende, minor chlorite replacing biotite, and calcite. Granite yields a $\mathrm{K}$-Ar age of $64.4 \pm 0.48 \mathrm{Ma}$ on biotite (map loc. 2; table 1)

TKgd Granodiorite-Light- to dark-gray, fine- to medium-grained, equigranular to porphyritic, biotite-hornblende granodiorite. Estimated mode: 45 percent plagioclase $\left(A n_{40-45}\right), 30$ percent quart2, 20 percent $\mathrm{K}$ feldspar, 2 percent hornblende, 2 percent biotite, and $<1$ percent zircon and calcite as accessories

Kgr1 Granite and granodiorite-Medium gray, medium- to coarse-grained, porphyritic, muscovite-biotite granite with potassium feldspar phenocrysis to one-half inch long and quartz phenocrysts to one-half inch in diameter; and medium to dark-gray, fineto medium-grained, biotite granodiorite. Locally unit contains abundant quartz veining. Quartz veinlets contain quartz crystals, muscovite. limonite, and specular hematite. Estimated modal composition of the granite phase: 45 percent microcline, 20 percent plagioclase $\left(A_{2} 20-25\right), 20$ percent quartz, 12 percent biotite, 2 percent white mica (muscovite?), <1 percent apatite, chlorite, zircon, and calcite as accessories. Biotite from granitic phase yields a $\mathrm{K}-\mathrm{Ar}$ age of $72.8 \pm 1.6 \mathrm{Ma}$ (map loc. 1; table I)

Kgr2 Granite-Light-gray, coarse-grained, equigranular to porphyritic, biotite granite with potassium feldspar phenocrysts to one-inch long. Estimated mode: 40 percent mictocline, 25 percent quartz, 20 percent plagioclase $\left(\mathrm{An}_{25-30}\right), 10$ percent biotite, 3 percent chlorite, 1 percent white mica (muscovite ?), and <l percent zircon, calcite, apatite and opaques as accessories

Kgr3 Granite-Light- to medium-gray, fine- to medium-grained, equigranular and porphyritic, muscovite-biotite granite with potassium feldspar phenocrysts to one-half inch long. Estimated mode: 45 percent microcline, 25 percent quartz, 25 percent plagioclase $\left(A n_{15-20}\right), 2$ percent biotite, 2 percent white mica (muscovite?), and $<$ percent zircon and apatite as accessories. Border phase is medium dark-gray, fine-grained, non-porphyritic biotite granite. Unit contains numerous pegmatite dikes and thin quartz-tourmaline veins. Granite yields a K-Ar age of $68.7 \pm 2.1 \mathrm{Ma}$ for biotite and $77.55 \pm 2.3 \mathrm{Ma}$ for muscovise (map loc. B; table 1)

Kgrd Granite and quartz monzonite-Light- to medium-gray, fine- to medium-grained, equigranular to porphyritic, biotite granite and gray, medium-grained, porphyritic quartz monzonite with potassium feldspar phenocryts to one-eighth inch long. Estimated mode for the granite: 45 percent microcline, 35 percent quartz, 17 percent plagioclase, 2 percent biotite, and $<$ percent muscovite and zircon as accessories. Unit contains abundant pegmatite dikes. Pegmatite dikes are medium to dark gray, medium- to coarsegrained, equigranular rocks containing quart2, plagioclase, white mica, biotite and garnet locally. Unit also contains zones of quarzz-tourmaline veining. $\mathrm{KgT} 4$ yields 
$\mathrm{K}-\mathrm{Ar}$ age of $73.5 \pm 2.5 \mathrm{Ma}$ for biotite and $77.6 \pm 2.0 \mathrm{Ma}$ for muscovite (map loc. 4 ; table 1)

Kgr5 Quartz monzonite and granite-Medium light-gray to gray, fine- to medium-grained, slightly porphyritic muscovite-biotite quartz monzonite and gray, fine- to mediumgrained, equigranular muscovite-biotite granite. Estimated mode for the granitic phase: $35-40$ percent microcline, 30-35 percent quartz, 22 percent plagioclase $\left(A n_{25-30}\right), 3$ percent biotite, and $<1$ percent muscovite and zircon as accessories. Locally unit has an incipient foliation

Kgd1 Granodiorite-Light- to medium-gray, fine-to coarse-grained, equigranular to porphyritic biotite-homblende granodiorite, and biotite granite. Estimated mode for the granodiorite: 45 percent plagioclase $\left(A n_{40-45}\right), 30$ percent quartz, 20 percent $\mathrm{K}$-feldspar, 2 percent hornblende, 2 percent biotite, and $<1$ percent zircon and calcite as accessories. Porphyritic phases contain abundant potassium feldspar phenocrysts and are biotite rich. Equigranular phases are fine grained, locally leucocratic, and contain minor amounts of white mica and tourmaline as accessories. Phenocrysts are poikilitic and contain abundant biotite inclusions. This pluton contains zones of abundant quartz veining as well as aplite dikes. Pluton yields $\mathrm{K}-\mathrm{Ar}$ age determinations ranging from $91.65 \pm 2.7$ to $96.34 \pm 2.9 \mathrm{Ma}$ (map locs. E, G, table 1)

Kgd2 Granodiorite-Medium- to dark-gray, medium- to fine-grained, equigranular hornblende-biatite granodiorite. Estimated mode: 35 percent plagioclase $\left(A n_{30-35}\right)$, 35 percent $\mathrm{K}$-feldspar, 25 percent quartz, 2 percent homblende, 2 percent biotite, and $<1$ percent chlorite, zircon, calcite, white mica, and apatite as accessories, Contains small (generally less than one-inch wide) dikelets of similar composition. Zones of dark-gray, fine-grained biotite granodiorite are present locally. Center of $\mathrm{Kgd} 2$ body is medium grained, grading to fine-grained border phase

Mawg Granite, granodiorite, and quartz monzonite-Medium-grained equigranular to porphyritic biotite-muscovite granite; medium-grained, porphyritic, biotite granite, and quartz monzonite; and dark-gray, fine- to medium-grained, biotite-hornblende granodiotice. Estimated mode of the granite: 45 percent $\mathrm{K}$-feldspar, 25 percent quartz, 25 percent plagioclase ( $\left.A_{25-30}\right)$, 3 percent biotite, and $<1$ percent chlorite and muscovite as accessories. All phases are massive without a planer or linear fabric. Unit intrudes rocks of the West Point complex. Pluton yields a $\mathrm{K}-\mathrm{Ar}$ age of 85.0 $\pm 2.5 \mathrm{Ma}$ on biotite (map loc. C; table 1 )

MzPzum Serpentinite-Medium-dark-green to dark green, fine- to medium-grained, highly altered serpentinite. Present as small isolated bodies or tabular masses along fault zones. Contains altered gabbroic rocks locally

\section{METAMORPHIC ROCK UNITS}

\section{Totatlanika Schist}

The Totatlanika Schist is the uppermost bedrock stratigraphic unit in the upper Chena River area. Approximately 8,000 feet of section is exposed in the southern part of the map area; the top of the unit is not exposed. The unit is in definite thrust-fault contact with the underlying Blackshell rock types in the southwestern part of the map area, and although not as well exposed, the thrust fault is thought to continue eastward where it may be cut by a large granodiorite body (unit Kgd l) from which 91$93 \mathrm{Ma} \mathrm{K}-\mathrm{Ar}$ ages have been determined (map locs. E, G; table 1). These radiometric ages may thus represent a minimum age for overthrust emplacement of the Totatlanika Schist over the Blackshell unit. Megafossils from the Totatlanika Schist in the Alaska Range are Late Devonian to Mississippian in age (Gilbert and Bundizen, 1979); and a U-Pb (zircon) age of felsic schist from the unit in the Kantishna Hills is $366 \mathrm{Ma}$ (T.K. Bundtzen, written commun., 1994).

A variety of Totatlanika Schist rock types occur in the upper Chena River area, including gray, green, or tan phyllites and semischists, phyllitic quartz arenites with poorly sorted to bimodal quartz grains (grits), and thinbedded to schistose marbles and calcschists. Although several of the rock types are probably metavolcaniclastic in origin, no extrusive metavolcanic rocks were found in this map area. Elsewhere, mafic and felsic metavolcanic rocks are a prominent component of the Totatlanika Schist (Wahrbaftig, 1970 a-b; Gilbert and Bundtzen, 1979)

Patm Marble-Massive- to thin-bedded, gray to creamy white marble interbedded with Pzig and Pstp. Garnet and epidote locally present. Siliceous webs and veinlets common 
in massive beds. Conpositionally gradational to Pztc

Patc Calcschist-Thinly layered, schistose calcareous rocks. Composition varies from impure micaceous marbles to biotitesericite-calcite-quartz schist with accessory tourmaline, ilmenite(?), and apatite. Interlayered with and gradational to Pztm. Most abundant near contact with Blackshell unit

Pztg Green phyllite and semischist-Pale- to dark-green phyllite, semischist, and phyllitic quartz arenite (grits) with foliated chlorite-sericite-plagioclase-quartz groundmass. Subrounded to angular quarzz clasts typically compose $35-50$ percent of the rock and are poorly sorted to bimodal with clast sizes to one-eighth inch in diameter. Plagioclase composition is $\mathrm{An}_{33-35}$. Unit includes some banded green chert with thin white carbonate laminations. Crenulations and kink folds are common. Abundant quartz veins and limonitic clots on foliation surfaces. Intricately folded near the contact with Pzbp

Patp Gray phyllite and semischist-Light- to dark-gray rocks, identical in texture and mineral content to Pztg but without green coloration. Mainly sericite-quartz with minor feldspar and trace chlorite. Smallscale folds and crenulations prevalent

Patt Tan phyllite and semischist-Tan-weathering phyllite, semiscbist, and meta-arenite. Identical to Pztg and Pztp except for more abuodant feldspar and minor biotite, and disseminated limonite throughout the rock imparts a tan coloration

Pztu Undifferentiated Totatlanika Schist-Includes several Pzt lithologies described above. Confined to east trending ridge in the southeastern part of the map area

\section{Blackshell and Dan Creek Units}

The Blackshell unit (units Pzbp, Pzbr, and Pzbc) and the Dan Creek unit (units Pzdc, Pzdp, and Pzdn) form a gradational sequence with an aggregate stratigraphic and structural thickness of 6,000-18,000 feet Both units are best exposed on the Iow ridges south of the Middle Fork of the Chena River in the westcentral map area. The units represent a transition upsection, both in composition and metamorphic grade, from calcareous, coarsely crystalline schists and marbles of the uppermost Chena River sequence through micaceous calcschists and marbles, quartzose calcphyllites and black quartzites (metachert ?), phyllitic quartzites, and phyllites of the Blackshell unit.

Mineral assemblages and textural advancement throughout the section indicate a transitional change from amphibolite facies at the bottom to greenschist facies in the upper section. This transition is similar to that observed in drill cores of the same stratigraphy from the Eielson deep test well, 50 miles southwest of the map area (Forbes and Weber, 1975). No abrupt changes in metamorphic grade, texture, structure, or lithology that would indicate fault juxtaposition of units were noted in the map area.

The Dan Creek and Blackshell units combined probably correlate with the Keevy Peak Formation and Birch Hill sequence in other parts of the Yukon-Tanana upland and northern Alaska Range (Gilbert and Bundzen, 1979; Robinson and others, 1990). No direct evideace of depositional age was found in outcrop; however, Favosites corals in siliceous calcphyllite float almost certainly derived from Pzdp were found in the Chena River drainage just west of the map area (W.A. Oliver, F.R. Weber, written commun., 1985). On this basis, the age of the Dan Creek unit is considered to be between Late Ordovician and Middle Devonian. The overlying Blackshell unit is comparable to upper parts of the Keevy Peak Formation in the Alaska Range, from which Middle and Upper Devonian megafossils have been collected (Gilbert and Redman, 1977; Gilbert and Bundtzen, 1979). Within this map area, a U-Pb model age of between $355.2 \pm 1.2 \mathrm{Ma}$ and $355.9 \pm 0.8 \mathrm{Ma}$ (fig. 4) was obtained on zircon from a rhyolite dome within the Blackshell unit (Pzbr), thus confirming a Late Devonian age for the southern part of the unit (J.K. Mortenson, written commun., 1989).

Pzbr Blackshell rhyolite - Light- to dark-brown weathering, quartz-K-feldspar porphyry dome and associated aphanitic vitreous muscovite- feldspar-quartz beds (metatuff, metaexhalite) near top of Pzbp unit. Rhyolite is porphyritic with white, Carlsbadtwinned, subhedral K-feldspar and rounded or embayed, gray beta-quartz phenocrysts in an aphanitic groundmass of sericite, feldspar, and quartz with disseminated pyrite blebs. Associated aphanitic, vitreous quartzite beds (metaexhalites?) in same stratigraphic horizon are finely laminated, muscovite-feldspar-quartz rock with altered feldspar and pyrite clots. U-Pb model ages of between $355.2 \pm 1.2 \mathrm{Ma}$ and $355.9 \pm 0.8 \mathrm{Ma}$ were obtained on zircons from rhyolite of this unit (J.K. Mortenson, 
Geological Survey of Canada, written commun., 1989; map loc. J; fig. 4)

Pzbp Blackshell quartzite and phyllite-A 4,000foot-thick sequence of black carbonaceous phyllite and fine-grained, dark, laminated quartzite with minor interbeds of calcschist and marble (Pzbc), rhyolite (Pzbr), and pebble to granule conglomerate. Unit is gradational with increase of carbonate to the Dan Creek calcphyllite below, and in this map area, is in thrust-fault contact with various lithologies of Totatlanika Schist above. Consists dominantly of dark-gray to black quartzite (metachert), phyllitic quartzite, thiniy laminated graphite-white mica, quartz phyllite, and black slate. Carbопасеous material typically 10-20 percent of the rock. Calcite and quartz segregations in boudins are common; limonite or pyrite is present along bedding lamination and disseminated throughout rock. Quartz veins and veinlets are abundant throughout the unit. Gray, white, or bluish-gray oxide coatings are visible on weathered surfaces. Refolding of small isoclinal folds has resulted in crenulated and warped axial planes of earlier folds. Sediments from streams draining Pzbp unit commonly enriched in zinc to several thousand parts per million. Considered correlative with upper part of the Keevy peak Formation in the Alaska Range, from which Middle and Upper Devonian megafossils have been collected (Gilbert and Bundtzen, 1979)

Pzbc Blackshell calcschist and marble-Tan to medium gray, calcite-rich beds interbedded with Pzdp unit; most common near gradational contact with the Dan Creek calcphyllite unit (Pzdp). Calcareous beds are typically 1-2 feet thick, interlayered and interfolded with black quartzite. Texture varies from paper-thin laminations of alternating carbonate and phyllite to banded, faintly schistose white mica-calcite quartzite. Carbonaceous concentrations along bedding traces and disseminated pyrite are present in most Pzbc units

Pzdc Dan Creek calcschist-Basal part of the Dan Creek unit, present mainly in the western part of the map area along the Middle Fork of the Chena River. Consists primarily of medium- to dark-gray muscovite-biotitecalcite-quartz schist with interbeds of white and gray marble (Pzdm), gray or black quartzite, and garnet-muscovite-quartz schist. Quartz boudins and veins common. Gradational to Chena River sequence below. Differentiated from Pzdp by the presence of coarse-grained white mica in schists

Pzdp Dan Creek calcphyllite-Interbedded silvery gray, calcareous phyllite; brown, gray, or black laminated quarzite, noncalcareous gray phyllite, and minor green phyllite and marble (unit Pzdm). Typical mineralogy is 80-85 percent quartz, 5 percent white mica, and 5-10 percent chlorite and graphite. Porphyroblastic biotite clasts present in some semischistose layers near gradational contact with Pzdc. White efflorescent coatings on weathered surfaces and abundant orange or brown weathering pits and laminations are characteristic. Quartz boudins, crenulations and crenulation cleavage are common features

Pzdm Dan Creek marble-Gray to white or greenish gray marble in Pzdc-Pzdp section. Coarsely crystalline with varying amounts of chlorite, muscovite, and quartz. Thinly laminated and fine-grained to massive and granoblastic

\section{Chens River sequence}

The Chena River sequence (CRS) is exposed best in a broad shallow synform in the eastern part of the map area. Its stratigraphic structural thickness is $4,000-8,000$ feet. Although bedded rocks of the sequence are apparently conformable with underlying quartzite units, the various lithologies of CRS record a strikingly different depositional environment. Metavolcanic rocks of felsic to mafic composition (Pzrf, Pzrp, Pzrn) are characteristic of CRS, as are diopside-rich quartzites (Pzrcs), thick marbles and calcschist (Pzrm, Pzrc), abundant pelitic schists (Pzrs), and concordant granitic augen gneiss bodies (Pzra). All CRS units have been metamorphosed in the amphibolite facies. A broad range of contrasting lithologies and striking continuity of individual beds are also characteristic of the Chena River sequence. Minor folds of hand-specimen to outcrop scale are evident in CRS as they are in other bedrock sequences in the upper Chena River area; the folds, however, seem to be mainly intraformational and do not markedly disrupt the lateral continuity of individual units.

Over most of the map area, the base of CRS is taken at the lowest green calcsilicate bed. The top of the 
sequence is gradational into the Dan Creek calcschist (Pzdc) and calcphyllite (Pzdp), a monotonous limy unit from which Favosites corals with an Ordovician to Middle Devonian age range have been recovered (W.A. Oliver; P.R. Weber, written commun., 1985). The underlying Chena River sequence is thus considered to be early Paleozoic in age and is correlated with a similar sequence of rocks in the Fairbanks mining district to the southwest (Smith and others, 1981; Robinson and others, 1990).

Pzira Augen gneiss-Mottled gray or brown and white, mainly concordant, grabitic augen gneiss bodies in Chena River sequence, upper Clinky quartzite, and West Point Complex. Typically weathers as flaggy plates or blocks, a few inches to several feet in diameter. Thickness of augen gneiss layers varies from a few inches to tens of feet: multiple thin layers are common. Composition ranges from quartz-rich varieties with $10-20$ percent $\mathrm{K}$-feldspar megacrysts (augen quartzite) to biotite - plagioclase-quartz-feldspar gneisses with 40-50 percent K-feldspar megacrysts. Augens up to 2 inches are lenticular, rounded, or subangular; consist of Carlsbad- and grid-twinned K-feldspar with plagioclase $\left(A n_{38}-40\right)$ inclusions and local relict perthitic textures. Small quartz grains are present in pressure shadows adjacent to megacrysts. Schistose groundmass consists of biotite-plagioclase- $K$-feldspar and quartz in varying proportions with accessory sphene, apatite, and ilmenite(?). Secondary chlorite and sericite are common, garnet is locally present. Major-element chemistry of selected augen gneiss samples is granitic (table 2 and fig. IA); biotite from the augen goeiss yields a K-Ar age of $76.7 \pm 1.5 \mathrm{Ma}$ (map loc. 3; table 1) and muscovite from the augen gneiss yields a $\mathrm{K}-\mathrm{Ar}$ age determination of $82.3 \pm 3.5 \mathrm{Ma}$ (map loc. 3; table 1). These ages are considered overprint ages from nearby Cretaceous granites. Although less calcic in composition (table 2), the augen gneiss bodies in the map area are similar to those in the central Big Delta Quadrangle, which are considered to be metamorphosed sill-like granitic intrusives of Mississippian age (Dusel-Bacon and Aleinikoff, 1985). U-Pb data from a small augen gneiss body in the eastem part of the map area (map loc. 5; fig. 6) confirm an Early Mississippian age. Field localities of the upper Chena River augen gneisses are enigmatic, however, in that (1) locally, many multiple units are delicately interlayered with metasedimentary host rocks, (2) in some cases, they appear gradational with enclosing host rocks, and (3) individual augen gneiss layers a few feet thick extend laterally over the same stratigraphic borizod for up to 15 miles. Thus, the field occurrence and geometry of many augen gneiss layers in the map area are more typical of recrystallized felsic volcanic rocks than of deep-seated intrusives

Pzrn Greenschist - Greenish-gray actinolite greenschists with variable mineralogy. Varieties include gamet-chlorite-muscovite-actinolite schist, biotite-muscovite-actinolite quartz schist, plagioclase-quartz-biotiteactinolite schist, and porphyroblastic garnet-chlorite-calcite-actinolite schist. Unit grades compositionally to micaceous amphibolite (Pzrp) and amphibolite (Pzrf). Contains zones of abundant white quartz veins and lenses

Pzrcs Calcsilicate rocks-Thin- to thick-bedded, light green to white units of diopside-bearing quartzite, diopside-calcite quartzite, and diopside-quarz marble. Most beds are somewhat calcareous with pod-like or lenticular calcite concentrations. Typically laminated or banded. Boudinage of quartzrich layers common. Interbedded with pelitic schists, amphibolites and siliceous marbles. Gamet, biotite, muscovite, $\mathrm{K}$-feldspar, and plagioclase $\left(\mathrm{An}_{30-33}\right)$ are present in some calcsilicate beds. Diopside content is typically $20-50$ percent. Contains rare tourmaline-rich horizons (former borosiliceous evaporites?). The Parcs rocks probably represent original dolomitic quarzites and siliceous dolomites. Tungsten skarn deposits are present in the upper Chena River area where Pzrcs and associated marbles (Pzrm) are cut by younger granitic bodies

Purs Pelitic schist and quartzite-Medium- to coarse-grained, silvery to bronze weathering pelitic schist and gray or brown 
micaceous quartzite. Schist-quartzite ratios in the Chena River sequence are about $4: 1$. Most commonly, garnet-feldspar-biotitemuscovite-quartz schist with varying amounts of minor minerals-staurolice. kyanite, sillmanite, homblende, graphite, and secondery chlorite, biotite, or sericite. Accessory tournaline, apatite, and sphene. Plagioclase is andesine $\left(\mathrm{An}_{33-40}\right)$; K-feldspar is grid twinned and perthitic; garnets are sieve textured or contain helicitic inclusions of quartz and feldspar; biotites have pleochroic balos around zircon and allanite(?). Quarzites in unit are foliated with biotite and muscovite to 20 percent; small reddish garnets and lenticular feldspar grains are present locally. Common textural features include crenulations, kink folds, crenulation cleavage, and small wavy or isoclinal folds. Garnet porphyroblasts to one-half inch in diameter form knobby foliation surfaces

Parf Banded amphibolite and felsite-Darkgreen, coarse-grained, schistose, hornblende-diopside -plagioclase-quartz amphibolite interlayered or interlaminated with muscovite-feldspar-quartz felsite. Garnet, biotite, and vesuvianite are minor minerals; sphene and ilmenite(?) are common accessories. Banded amphibolite sections locally include beds 2-6 inches thick of white laminated micaceous quartzite or beds of silvery-brown pelitic schist. Pzrf rocks were probably recrystallized from mafic, intermediate, and felsic tuffs

Pzrc Calcschist-White to gray, thin-layered quartz-muscovite-biotite-calcite schist. Typically very schistose fabric with "sureaked out" muscovite or biotite. Clinozoisite and plagiociase are minor minerals; tourmaline and sphene are accessories. Interbedded with pelitic schist (Pzrs), marble (Pzrm), or forms lenticular interbeds in green calcsilicare units (Pzrcs)

Parm Marble-Cream-colored, gray, or pale-green marble layers to 180 feet thick. Massive to thinly bedded. Contains zones with quartz-rich horizons. Marbles grade compositionally to calcschists (Pzrc) with paper-thin bedding and layers of garnetmuscovite-biotite quartz schist. Gray and greenish marbles contain varying amounts of gamet, diopside, and clinozoisite. Limonitic pits and stains along bedding are locally present. Commonly associated with calcsilicate beds (Pzrcs) and amphibolite (Pzrp)

Pzrp Massive amphibolite-Dense, fine- to medium-grained, dark-green, schistose amphibolite with varying amounts of biotite, garnet, plagioclase, calcite, and quartz. Associated with thin foliated marble layers and pelitic schist. Accessory sphene and ilmenite. Calcite veinlets common. Unit probably recrystallized from mafic volcanic flows and calcareous mafic tuffs

Purg Graphitic schist-Gray to black, micaceous quartz schist with abundant graphite. Grades compositionally to slightly graphitic pelitic schist (Pzrs)

\section{Quartzite-dominant basement units}

The lowest stratigraphic units in the map area are best exposed in the northem and eastern pars of the upper Chena River area. Their aggregate stratigraphic or structural thickness is at least 10,000 feet. They consist dominantly of metaquartzite, pelitic schist, and minor marble and are represented by map units $\mathrm{pCu}$ and Clinky quartzite $(\mathrm{pCc}, \mathrm{pCcm})$. The quartzites vary in texture and composition from platy, mostly pure quarzite of uniform grain size typical of the Clinky quartzite $(\mathrm{pCcq})$ to thick-bedded feldspathic quartzite with numerous subrounded quartz "eyes" (grits) that are most common in the unit $\mathrm{pCu}$ along the northem part of the map area. The various quartzite types and associated pelitic schists appear to have recrystallized from well- to poorly sorted and bimodal quartz arenites or granule conglomerates with varying proportions of shale interbeds. Although the quarzites differ slightly in texture and composition, the quartzite-dominant units appear to represent a similar provenance and depositional environment. The variations in quartite texture, composition, quartzite-schist ratio, and quarzite bed thicknesses between units $\mathrm{pCu}$ and $\mathrm{pCcq}$ may be related to original depositional facies of submarine fans as demonstrated in the nearby Lime Peak-Mr. Prindle area (Smith, Pessel, and Wiltse, 1987). Alternatively, the variations have been explained by inferred premetamorphic thrust fault juxtaposition of the various quartzite types (Foster and others, 1983). The prevalence of small-scale intraformational isoclinal folding in these basement rocks indicates structural thickening of the units. The quartzite-dominant units in this map area are considered to be late Precambrian in age and correlative with the Fairbanks Schist, the lowest stratigraphic unit exposed 
in the Fairbanks mining district (Smith and otbers, 1981; Robinson and others, 1990).

pCeq Clinky quartzite-Thickness 3,000-10,000 feet. Dominantly thin- to medium-bedded, gray quartzite with lesser bronze- or silvery- weathering pelitic schist and minor marble $(\mathrm{pCcm})$. The proportion of schist in the unit varies both laterally across the area and vertically within the section; uppermost part of the unit has quartzite/schist ratio of about 1:1, lower part about 6 or 8:1. Quarzites are typically thin-bedded, banded, gray rocks; a few contain "streaky" chalky-weathering feldspar and sparse gray quartz "eyes." Muscovite and biotite content of quartzite ranges to 10 percent; small red garnets are present locally. Pelitic schist is typically medium- to coarse-grained, garnet-biotite-muscovite quartz schist, Garnet porphyroblasts to one-half incb in diameter form knobby schistosity surfaces. $\mathrm{K}$-feldspar and untwinned plagioclase are minor minerals; tourmaline is a common accessory; chlorite and sericite replace garnet, biotite, and feldspar. Crenulations in two directions, minor folds, crenulation cleavage, and ribbon-textured quartz are ubiquitous structural elements. Quartz veins are rare; aplites and tourmaline-bearing pegmatites are present locally. Bedding in unit is parallel to that in the overlying Chena River sequence. The Clinky quarnzite and West Point Complex are intruded by an orthogneiss body from which a $\mathrm{U} \sim \mathrm{Pb}$ (zircon) age of $671 \pm 34 \mathrm{Ma}$ has been determined (J.N. Aleinikoff, U.S. Geological Survey, written commun., 1984; map loc. V; fig. 5)

pCcm Marble-Interbedded with PzpCeq. Forms beds of gray, white, or pale-green marble to 20 feet thick. Variations include grayweathering, banded, coarse-grained marble; brown and white, laminated, sugary-textured nonschistose marble; and fine-grained, greenish-gray, impure marble containing feldspar, quartz, and diopside to 20 percent. Limonitic clots are common in marble. Presence of diopside indicates metamorphism in amphibolite facies

$\mathrm{PCu} \quad$ Undifferentiated quartxite and schist- $\mathrm{Ex}$ posed in northem part of the map area. Thickness at least 4,000 feet. Consists dominantly of platy-or blocky-weathering. gray or tan, slightly feldspathic quartzite and medium- to coarse-grained pelitic schist. Quartzite is typically micaceous with muscovite and biotite to 25 percent; some horizons, wbich may represent channel fills in a submarine fan, contain several percent feldspar as grid-twinned $\mathrm{K}$-feldspar and untwinned plagioclase. Bimodal quartzites (grits) with clear to smoky quartz "eyes" to one-quarter inch in diameter are present locally. Pelitic schists are medium gray, brownish gray, or silvery gray, garnet-biotite-feldspar-muscovitequartz schists. Retrograde chlorite and muscovite replace gamet, biotite, and plagioclase locally; tourmaline and graphite are common accessory minerals; staurolite is present locally. Crenulations, kink folds, crenulation cleavages and small isoclinal folds are prevaleut structural elements in outcrop. Quartz veins and tourmaline-quartz veins are locally abundant, especially near granitic plutons. Although bedding attitudes in pCu appear to be parallel with those in the overlying Cheng River sequence, the unit is considered to be in thrust fault contact with the sequence as suggested by Foster and others (1983)

pCm Marble-Massive, cream to white, coarse grained, diopside-tremolite- or actinolitebearing marble. Weathers medium gray to chalky white; locally laminated with biotite and pink or brown garnet. Marbles grade compositionally to calcite-bearing pelitic schist

\section{West Point Igneous/Metamorphic Complex}

The West Point Complex is exposed in the eastcentral part of the map area and consists of upper amphibolite facies metamorphic rocks that were intruded by abundant pre- and post-metamorphic, felsic to intermediate igneous rocks. Boundaries of the complex are gradational. Host rock protoliths include various lithologies of the Clinky quartzite ( $\mathrm{pCcq}, \mathrm{pCcm}$ ) and possibly other basernent units, such as those exposed in the northern part of the map area ( $\mathrm{pCu}$ ). The U-Pb model age of $671 \pm$ $34 \mathrm{Ma}$ from zircon in a premetamorphic intrusive body ( $\mathrm{pCwo}$ ) establishes a late Precambrian or earlier depositional age for protoliths in the West Point Complex (J.N. Aleinkoff, U.S. Geological Survey, written commun., 1984; map loc. V; fig. 5). Pelitic schists of the 
complex locally contain silkmanite and characteristically show a pronounced segregation of micaceous and quartzofeldspathic layers-a texhural property rarely seen outside the complex. Most igneous bodies are sill- or dikelike in form and are too small to differentiate at this map scale. However, in some areas they constitute 20-30 percent of the bedrock. They include a variety of foliated and nonfoliated granites, granodiorites, aplites, augen gneiss, pegmaties, and minor metabasites.

pCwo Orthogneiss-Foliated, muscovite-biotite granitic orthogneiss bodies within metamorphic complex. Contacts with paragneiss (pCwp) usually gradational. Most bodies contain muscovite and garnet; some contain blastophenocrysts of K-feldspar. Microtextures are cataclastic witb deformed or granulated feldspar and quartz, numerous micaceous slip surfaces and secondary white mica replacing biotite. Plagioclase is normally zoned $\left(\mathrm{An}_{35-55}\right)$, $\mathrm{K}$-feldspars are mainly grid iwinned. Orthogneiss body $\mathrm{pCwo}$ (map loc. V; tables 1 , 2) yielded a $\mathrm{K}$-Ar age determination of $89.8 \pm 2.7 \mathrm{Ma}$ for biotite; this age is interpreted as a thermal overprint from numerous unmetamorphosed Cretaceous and Tertiary age plutons in the area. A $\mathrm{U}-\mathrm{Pb}$ model age of $671 \pm 34 \mathrm{Ma}$ was obtained on zircon from orthogneiss of this unit (J,N, Aleinikoff, U.S. Geological Survey, written commun., 1984; map loc. V; fig. 5). On this basis, the premetamorphic intrusive age of the orthogneiss is considered to be late Precambrian

pCwp Paragneiss - Light- to dark-gray, gray- or tanweathering paragenesis, includes thin- to thick-bedded quartzite and interbedded pelitic gneiss, granitic augen gneiss, marble (pCwm), and abundant igneous and metaigneous rocks. Layering of paragneiss is planar to highly contorted: individual layers are usually dismembered, boudinaged, or lenticular. Quartz boudins are common. Schists contain varying amounts of quartz, plagioclase, biotite, muscovite, and garnet with minor sillimanite, ampbibole, and tourmaline. Plagioclase $\left(\mathrm{An}_{25-30}\right)$ is typically unzoned, garnet is sieve textured; quartz is sutured to polygonal; chlorite locally replaces biotite and garnet. Disseminated chalky, white-weathering feldspar grains are present in some quartzites. Unit is cut by numerous tourmaline-quartz veins and with loss of gneissic character around margins is gradational to Clinky quarlzite (pCcq). Northern part of the complex contains sparse augen gneiss layers to 10 feet thick that are similar to augen gneiss ( $\mathrm{Pzra}$ ) units upsection

pCwm Marble- White to light gray, buff weathering. coarse-grained, diopside- and quartz-bearing marble. Typically present in contorted layers with boudinaged and stretched quartzite or diopside-bearing quartzite interbeds. Marble is generally associated with pelitic paragneiss

\section{REFERENCES CITED}

Dubois, G.D., Wilson, F.H., and Shew, Nora, 1986, Map and tables showing potassium-argon determinations and selected major-element chemical analyses from the Circle Quadrangle, Alaska: U.S. Geological Survey Open-File Report 86-392, 1 sheet, scale $1: 250,000$.

Dusel-Bacon, Cynthia, and Aleinikoff, J.N., 1985, Petrology and tectonic significance of augen gneiss from a belt of Mississippian granitoids in the YukonTanana terrane, east-central Alaska: Geological Society of America Bulletin, v. 96, p. 411-425.

Forbes, R.B., and Weber, F.R., 1975, Progressive metamorphism of schists recovered from a deep drill hole near Fairbanks, Alaska: U.S. Geological Survey Journal of Research, v. 3, no. 6, p. 647-657.

Foster, H.L., Laird, Jo, Keith, T.E.C., Cushing, G.W., and Menzie, W.D., 1983, Preliminary geologic map of the Circle Quadrangle, Alaska: U.S. Geological Survey Open-File Report 83-170A, 30 p., 2 plates, 1 map, scale 1:250,000.

Foster, H.L., Menzie, W.D., Cady, J.W., Simpson, S.L., Aleinikoff, J.N., Wilson, F.H., and Tripp. R.B., 1987, The Alaska mineral resource assessment program: Background information to accompany folio of geologic and mineral resource maps of the Circle Quadrangle, Alaska: U.S. Geological Survey Circular 986, p. 5 .

Gilber, W.G., and Bundtzen, T.K, 1979, Mid Paleozoic tectorics, volocanism and mineralization in northcentral Alaska Range in Proceedings of the Alaska Geological Society: The relationship of plate tectonics to Alaskan geology and resources: Alaska Geological Society v. 3, 26 p. 
Gilbert, W.G, and Redman, Earl, 1975, Geologic map and structure sections of the Healy C-6 Quadrangle, Alaska: Alaska Division of Geological \& Geophysical Surveys Open-File Report AOF-80, 3 p., 1 sheet, scale $1: 40,000$.

Keith, S.B., Laux, D.D., Meughan, K.S., Ruff, S., Swan, M.M., Abbott, E., and Friberg, S., 1991, Magma series and metallogeny: a case study from Nevada and environs in Guidebooks for Field Trips, v. 1, field trip no. 8, Reno, Nevada, Nevada Geological Society, p. 404-493.

Newberry, R.J., Burns, L.E., Swanson, S.E, and Smith, T.E., 1990, Comparative petrologic evolution of $\mathrm{Sn}$ and $\mathrm{W}$ granites of Fairbanks-Circle area, interior Alaska in Stein, H.J., and Hannah, J.L., eds., Orebearing granite systems: Geological Society of America Special Paper 246, p. 121-142.

Robinson, M.S., Smith, T.E., and Metz, P.A., 1990, Bedrock geology of the Fairbanks mining district: Alaska Division of Geological \& Geophysical Surveys Professional Report 106, 2 sheets, I map, scale 1:63,360.

Smith, T.E., Robinson, M.S., Bundkzen, T.K., and Metz, P.A., 1981, Fairbanks mining district in $1981-$ New look at an old mineral province [abs.]: The Alaska Miner, Journal of the Alaska Miner's Association, v. 9 , no. 11, p. 8 .

Smith, T.E., Pessel, G.H., and Wiitse, M.A., 1987, Mineral assessment of the Lime Peak - Mt. Prindle area, Alaska: Alaska Division of Geological \& Geophysi$\mathrm{cal}$ Surveys unpublished contract report, v. 1,711 p.

Streckeisen, A.L., and Le Maitre, R.W., 1979, A chemical approximation to the model QAPF classification of the igneous rocks: neues Jahrbook Mineral. Abh., v. 136, p. 169-206.

Solie, D.N., Burns, L.E., and Newberry, R.J., 1990, Gold favorability in the Big Delta Quadrangle, Alaska, as predicted by discriminant analysis for nonporphyry granitic rocks: Alaska Division of Geological \& Geophysical Surveys Public-Data File Repor 90-13. $17 \mathrm{p.}, 1$ sheet, scale 1:250,000.

Wahrhaftig, Clyde, 1968, Schists of the central Alaska
Range: U.S. Geological Survey Bulletin 254-E, 22 p. 1970a, Geologic map of the Healy D-2 Quadrangle, Alaska: U.S. Geological Survey Map GO-804. I sheet, scale 1:63,360.

$1970 b$, Geologic map of the Healy D-3 Quadrangle, Alaska: U.S. Geological Survey Map GO-805, 1 sheet, scale 1:63,360.

1970c, Geologic map of the Healy D-4 Quadrangle, Alaska: U.S. Geological Survey Map GO-806, I sheet, scale 1:63,360.

1970d, Geologic map of the Healy D-5 Quadrangle, Alaska: U.S. Geological Survey Map GO-807, 1 sheet, scale 1:63,360.

1970e, Geologic map of the Fairbanks A-2 Quadrangle, Alaska: U.S. Geological Survey Map GO-808, 1 sheet, scale 1:63,360.

1970f, Geologic map of the Fairbanks A-3 Quadrangle, Alaska: U.S. Geological Survey Map GO-809, I sheet, scale 1:63,360. $1970 \mathrm{~g}$. Geologic map of the Fairbanks A-4 Quadrangle, Alaska: U.S. Geological Survey Map GO-810, I sheet, scale $1: 63,360$.

1970h, Geologic map of the Fairbanks A-5 Quadrangle, Alaska: U.S. Geological Survey Map GO-811. 1 sheet, scale 1:63,360.

Weber, F.R., Foster, H.L., Keith, T.E. and Dusel-Bacon, Cynthia,1978, Preliminary geologic map of the Big Delta Quadrangle, Alaska: U.S. Geological Survey Open-File Report 78-0529A, 1 sheet, scale $1: 250,000$.

White, A.J.R.,and Chappel, B.W., 1983, Granitoid types and their distribution in the Lachlan fold belt, southeast Australia, in Roddick, J.C., ed., Circum Pacific piutonic terranes: Geological Society of America Memoir 159, p. 21-34.

Wilson, F.H., and Shew, Nora, 3981, Map and tables showing preliminary results of polassium-argon age studies in the Circle Quadrangle, Alaska, with a compilation of earlier dating work: U.S. Geological Survey Open-File Report 81-889, 1 sheet, scale $1: 250,000$. 


\section{FIGURES}




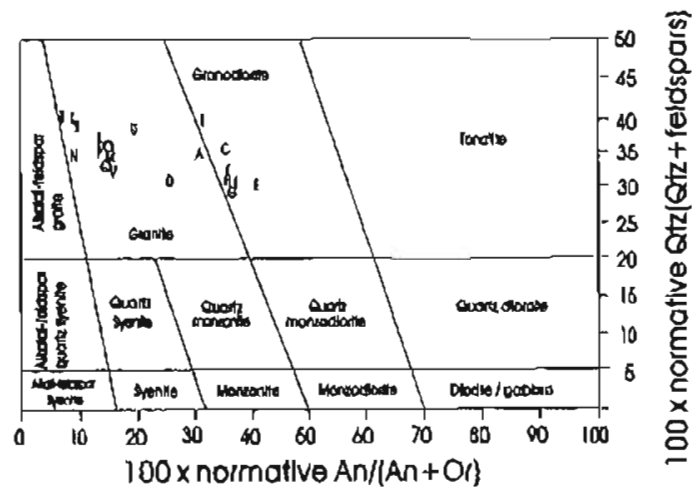

Figure 1A. Streckheisen plot of igneous rock classification (after Streckheisen and Le Maitre, 1979). Letters refer to map and to rables 1 and 2.

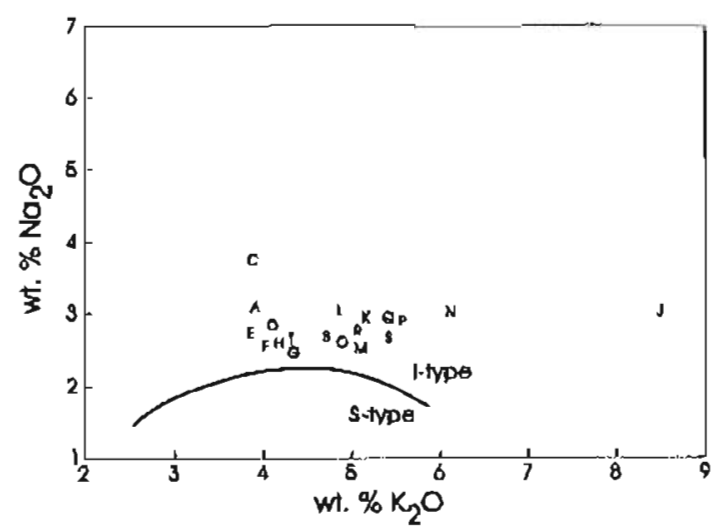

Figure 2A. Plot of $\mathrm{Na}_{2} \mathrm{O}$ versus $\mathrm{K}_{2} \mathrm{O}$. Contains the I and S boundary of White and Chappel (1983). Letsers rejer to map and to sables 1 and 2.

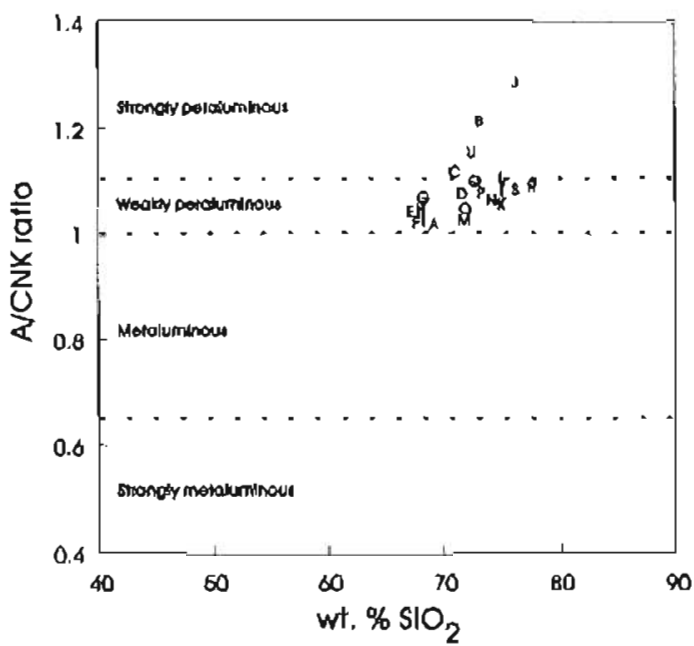

Figure 1B. Plot of A/CNK ratio (wr\% $\mathrm{Al}_{2} \mathrm{O}_{\mathrm{J}} /$ wr $\% \mathrm{CaO}$ $+w t \% \mathrm{Na}_{2} \mathrm{O}+w t \% \mathrm{~K}_{2} \mathrm{O}$ ) (after Keith and others. 1991). Letters refer to map and to tables 1 and 2.

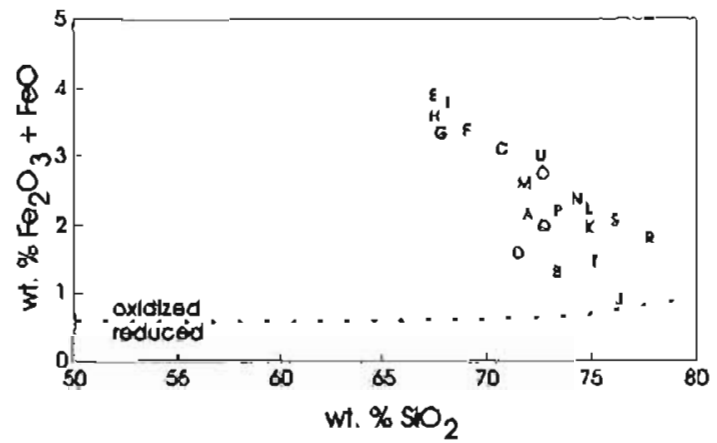

Figure 2B. Plot of $\mathrm{Fe}_{2} \mathrm{O}_{3}+\mathrm{FeO}$ (afier Keith and others, 1991). Letters refer to map and to tables 1 and 2.

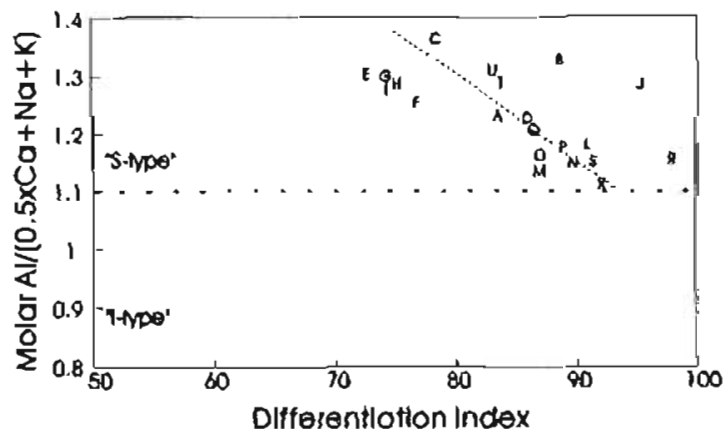

Figure 3. Molar A $/(0.5 \mathrm{Ca}+\mathrm{Na}+\mathrm{K})$ versus differentiation index plot (afier Newberry and others, 1990). Letters refer to map and to rables 1 and 2. 


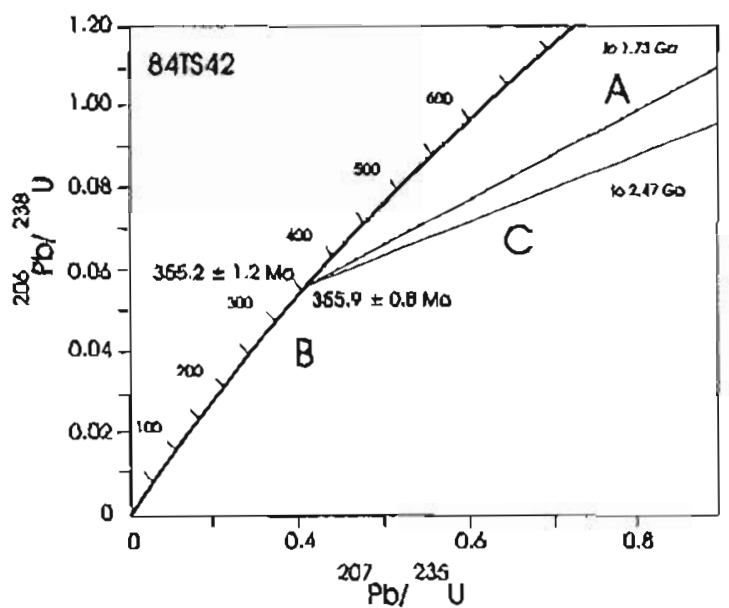

Figure 4. Plot of uranium-lead model age for zircon from rhyolite of the Blackshell unit (Pzbr), map location J. Age determined by J.K. Mortenson, Geological Survey of Canada (written commun., 1989).

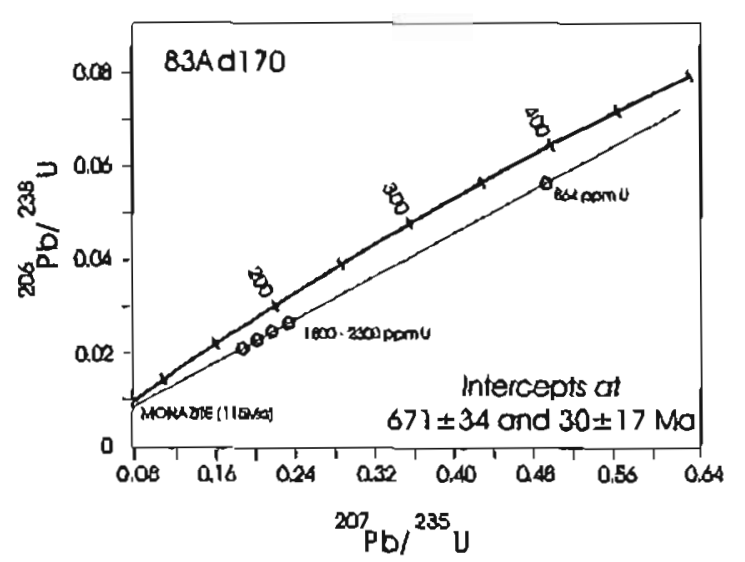

Figure 5. Plot of uranium-lead model age for zircon from orthogneiss of the West Point complex ( $p C w o$ ), map location V. Age determined by J. Aleinikoff, U.S. Geological Survey (written commun., 1984).

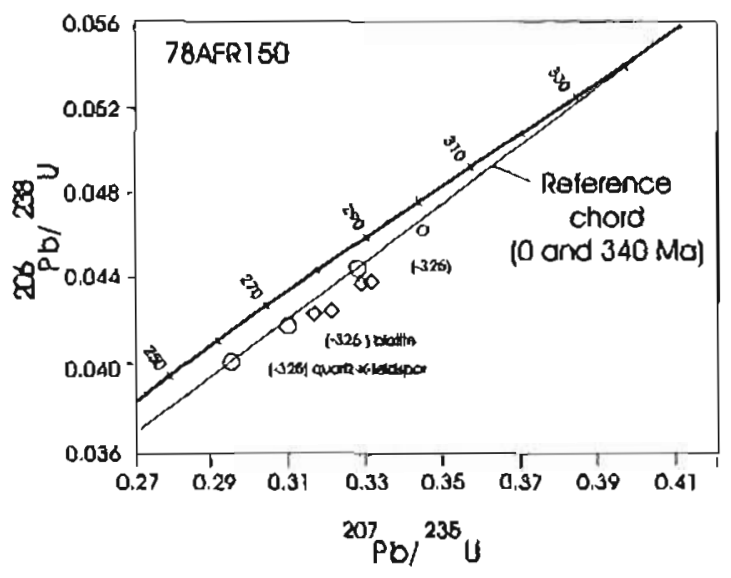

Figure 6. Uranium-lead concordia plot of zircon dala from augen gneiss of the Chena River sequence (Pzra), in eastem map area, map location 5 (Foster and others, 1987). 


\section{TABLES}


Table 1. Potassium-argon age dates of igneous and metamorphic rocks in the Upper Chena River region

\begin{tabular}{|c|c|c|c|c|c|c|c|c|c|}
\hline $\begin{array}{c}\text { Map } \\
\text { location }\end{array}$ & $\begin{array}{l}\text { Fieid } \\
\text { number }\end{array}$ & $\begin{array}{l}\text { Map } \\
\text { unit }\end{array}$ & $\begin{array}{l}\text { Mineral } \\
\text { dated }\end{array}$ & $\begin{array}{l}\mathrm{K}_{2} \mathrm{O} \\
\mathrm{wt} \%\end{array}$ & $\begin{array}{l}\text { \%K } \mathrm{O} \\
\text { aver }\end{array}$ & $\begin{array}{l}{ }^{+0} \mathrm{Ar}_{\text {rad }} \times 10^{-10} \\
\text { moles } / \mathrm{gm}\end{array}$ & ${ }_{\%}^{40} \mathrm{Ar}_{\text {rad }}$ & $\begin{array}{c}\text { Age }^{2} \\
\operatorname{Ma} \pm 1 \sigma\end{array}$ & Source \\
\hline $\mathrm{B}$ & $84 \mathrm{TS} 48$ & Kgr3 & muscovite & $\begin{array}{l}10.317 \\
10.285\end{array}$ & 10.301 & 11.74934 & 86.53 & $77.55 \pm 2.3$ & This study \\
\hline B & & & biotite & $\begin{array}{l}8.660 \\
8.653 \\
8.657\end{array}$ & 8.730 & 91.5 & & $68.70 \pm 2.1$ & do \\
\hline $\mathrm{C}$ & $84 T S 46$ & Mzwg & biotite & $\begin{array}{l}8.820 \\
8.817\end{array}$ & 8.818 & 11.047 & 94.4 & $85.00 \pm 2.5$ & do \\
\hline $\mathrm{E}$ & $84 T S 44$ & Kgd1 & biotite & $\begin{array}{l}8.610 \\
8.597\end{array}$ & 8.604 & 11.87330 & 94.33 & $93.41 \pm 2.8$ & do \\
\hline $\mathrm{E}$ & & & homblende & 0.970 & 0.970 & 1.38172 & 84.66 & $\begin{array}{c}96.34 \pm 2.9 \\
\text { (minimum age) }\end{array}$ & do \\
\hline$G$ & $84 \mathrm{TS} 45$ & $\mathrm{Kgdl}$ & hornblende & $\begin{array}{l}0.993 \\
1.000 \\
0.987\end{array}$ & 0.993 & 1.34427 & 83.46 & $91.65 \pm 2.7$ & do \\
\hline$G$ & & & biosite & $\begin{array}{l}8.968 \\
8.938\end{array}$ & 8.953 & 12.113 & 94.5 & $92.40 \pm 2.8$ & do \\
\hline $\mathrm{H}$ & $84 \mathrm{TS} 43$ & $\mathrm{Kgd2}$ & biotite & $\begin{array}{l}8.470 \\
8.482\end{array}$ & 8.476 & 11.88850 & 92.51 & $94.90 \pm 2.8$ & do \\
\hline H & & & homblende & $\begin{array}{l}0.607 \\
0.629 \\
0.607\end{array}$ & 0.618 & 0.87899 & 78.62 & $96.27 \pm 2.9$ & do \\
\hline v & $83 \mathrm{Ad} 170$ & PzpCwo & biotite & $\begin{array}{l}8.967 \\
8.940\end{array}$ & 8.953 & 11.866 & 95.7 & $89.80 \pm 2.7$ & do \\
\hline 1 & $79 \mathrm{AWr} 583$ & Kgrl & biotite & $\begin{array}{l}8.90 \\
8.89 \\
8.91 \\
8.94\end{array}$ & $\begin{array}{l}8.91 \\
9.632\end{array}$ & 9.415 & 85.6 & $72.8 \pm 1.6$ & U.S.G.S. OFR 86-392 \\
\hline 2 & 78AWr288 & $\mathrm{Tgr}$ & biotite & $\begin{array}{l}9.28 \\
9.30\end{array}$ & $\begin{array}{l}9.29 \\
8.744\end{array}$ & 8.796 & $\begin{array}{l}80.3 \\
79.3\end{array}$ & $64.4 \pm 0.48$ & U.S.G.S. OFR $81-889$ \\
\hline 3 & 79 Aws $105 a$ & Pzra & biotite & $\begin{array}{l}9.34 \\
9.23 \\
9.30 \\
9.19\end{array}$ & 9.27 & $\begin{array}{l}10.310 \\
10.482 \\
10.548\end{array}$ & $\begin{array}{l}48.31 \\
79.37 \\
80.30\end{array}$ & $76.7 \pm 1.5$ & U.S.G.S. OFR $86-392$ \\
\hline 3 & & & muscovite & $\begin{array}{l}10.42 \\
10.37 \\
10.38 \\
10.46\end{array}$ & 10.41 & $\begin{array}{l}12.976 \\
12.253\end{array}$ & $\begin{array}{l}91.9 \\
92.9\end{array}$ & $82.3 \pm 3.5$ & do \\
\hline 4 & $78 \mathrm{AWr} 286$ & $\mathrm{Kgr} 4$ & biosite & $\begin{array}{l}8.51 \\
8.63 \\
8.51 \\
8.63\end{array}$ & 8.57 & 9.265 & 79.7 & $73.5 \pm 2.5$ & U.S.G.S. OFR $81-899$ \\
\hline 4 & & & muscovite & $\begin{array}{l}10.90 \\
10.91 \\
10.89 \\
10.94\end{array}$ & 10.91 & 12.45 & 81.6 & $77.6 \pm 2.0$ & do \\
\hline
\end{tabular}


Table 2. Whole-rock major-axide analyses and CIPW normative mineralogy of igneous rocks in the southcentral Circle and northcentral Big Delta Quadrangles

\begin{tabular}{|c|c|c|c|c|c|c|c|c|c|c|c|c|c|c|c|c|c|c|c|c|c|c|}
\hline Map location & A & B & $c$ & $\mathrm{D}$ & $\mathrm{E}$ & $\mathrm{F}$ & $\mathrm{G}$ & $\mathrm{H}$ & I & $\mathrm{J}$ & $\mathrm{K}$ & $\mathbf{L}$ & M & $\mathrm{N}$ & 0 & $P$ & $\mathrm{Q}$ & $\mathbf{R}$ & $\mathrm{s}$ & $\mathrm{T}$ & $\mathrm{u}$ & $\mathrm{v}$ \\
\hline Map unit & $\mathrm{Kgr} 1$ & $\mathrm{Kgr} 3$ & Mzwg & $\mathrm{Kgr5}$ & Kgdl & Kgdl & Kgdl & $\mathrm{Kgd} 2$ & $\mathrm{Kgd2}$ & Pzbr & Pzara & Pzra & Pzra & Pzra & Pzra & Pzra & Pzra & Pzra & Para & PapCwp & PzpCwo & PzpCwo \\
\hline Field number & 2880 & $84 \mathrm{TS} 48$ & 84TS46 & 2890 & $84 \mathrm{TS} 44$ & 2911 & 84TS45 & $84 \mathrm{TS43}$ & $84 \mathrm{TS} 43 \mathrm{~b}$ & $84 \mathrm{TS} 42$ & 2878 & 2873 & 2881 & 5448 & 2869 & $84 \mathrm{TS} 47$ & 5440 & 5439 & 5438 & $5443^{\circ}$ & 5442 & 83Ad 170 \\
\hline \multicolumn{23}{|c|}{ Chemical analyses (weight percent) } \\
\hline $\mathrm{SiO}_{2}$ & 71.80 & 73.27 & 70.64 & 71.34 & 67.92 & 68.96 & 68.14 & 68.07 & 68.06 & 76.24 & 74.83 & 74.98 & 72.00 & 74.14 & 72.49 & 73.46 & 72.55 & 77.68 & 76.05 & 75.17 & 72.37 & 72.56 \\
\hline $\mathrm{Al}_{2} \mathrm{O}_{3}$ & 14.14 & 14.98 & 15.00 & 14.97 & 15.41 & 14.41 & 15.37 & 14.91 & 15.09 & 12.29 & 12.38 & 12.39 & 13.18 & 13.50 & 13.06 & 13.46 & 14.15 & 12.62 & 12.95 & 14.59 & 14.44 & 15.36 \\
\hline $\mathrm{Fe}_{2} \mathrm{O}_{3}$ & 0.44 & 0.27 & 0.64 & 0.32 & 0.80 & 0.73 & 0.73 & 0.75 & 0.78 & 0.19 & 0.42 & 0.45 & 0.58 & 0.49 & 0.59 & 0.46 & 0.60 & 0.38 & 0.66 & 0.29 & 0.63 & 0.28 \\
\hline $\mathrm{FeO}$ & 1.64 & 0.99 & 2.41 & 1.22 & 3.01 & 2.73 & 2.75 & 2.84 & 2.94 & 0.71 & 1.58 & 1.69 & 2.17 & 1.83 & 2.21 & 1.72 & 1.35 & 1.45 & 1.39 & 1.11 & 2.36 & 1.06 \\
\hline $\mathrm{MgO}$ & 0.50 & 0.35 & 0.78 & 0.43 & 1.29 & 1.03 & 1.19 & 1.40 & 1.45 & 0.13 & 0.27 & 0.30 & 0.50 & 0.46 & 0.56 & 0.39 & 0.58 & 0.49 & 0.31 & 0.20 & 0.92 & 0.39 \\
\hline $\mathrm{CaO}$ & 2.22 & 1.17 & 2.66 & 1.82 & 3.44 & 2.87 & 3.13 & 3.06 & 3.17 & 0.05 & 0.62 & 0.72 & 1.23 & 0.93 & 1.24 & $\{.15$ & 1.26 & 0.70 & 0.82 & 2.44 & 1.60 & 1.37 \\
\hline $\mathrm{Na}_{2} \mathrm{O}$ & 3.17 & 3.09 & 2.68 & 3.73 & 2.75 & 2.71 & 2.65 & 2.52 & 2.57 & 0.19 & 3.02 & 2.80 & 3.04 & 2.61 & 2.99 & 2.67 & 2.84 & 2.88 & 2.78 & 2.78 & 2.64 & 2.93 \\
\hline $\mathrm{K}_{2} \mathrm{O}$ & 3.96 & 4.75 & 3.87 & 4.16 & 3.87 & 4.07 & 4.31 & 4.30 & $4 . \hat{3} 0$ & 8.48 & 5.16 & 4.89 & 5.08 & 6.14 & 4.86 & 5.55 & 5.49 & 5.13 & 5.44 & 4.18 & 4.88 & 5.42 \\
\hline $\mathrm{TO}_{2}$ & 0.28 & 0.19 & 0.41 & 0.21 & 0.50 & 0.44 & 0.44 & 0.48 & 0.49 & 0.22 & 0.28 & 0.33 & 0.44 & 0.39 & 0.44 & 0.35 & 0.44 & 0.31 & 0.26 & 0.09 & 0.47 & 0.14 \\
\hline $\mathrm{P}_{2} \mathrm{O}_{5}$ & 0.06 & 0.16 & 0.13 & 0.07 & 0.12 & 0.08 & 0.11 & 0.15 & 0.14 & 0.09 & 0.06 & 0.06 & 0.08 & 0.14 & 0.10 & 0.10 & 0.14 & 0.14 & 0.08 & 0.06 & 0.17 & 0.07 \\
\hline $\mathrm{MnO}$ & 0.06 & 0.03 & 0.06 & 0.03 & 0.09 & 0.07 & 0.08 & 0.08 & 0.08 & 0.01 & 0.03 & 0.04 & 0.05 & 0.04 & 0.05 & 0.04 & 0.05 & 0.02 & 0.03 & 0.03 & 0.06 & 0.03 \\
\hline LOI & 2.30 & 0.67 & 0.61 & 0.51 & 0.43 & 0.14 & 0.55 & 0.77 & 0.59 & 1.03 & 0.38 & 0.42 & 0.40 & 0.60 & 0.46 & 0.23 & 0.46 & 0.71 & 0.51 & 1.56 & 3.32 & 0.50 \\
\hline Total & 100.57 & 99.92 & 99.89 & 98.81 & 99.63 & 98.24 & 99.45 & 99.33 & 99.66 & 99.63 & 99.03 & 99.07 & 98.75 & 101.27 & 99.05 & 99.58 & 99.91 & 102.51 & 10128 & 102.50 & 103.86 & 100.11 \\
\hline \multicolumn{23}{|c|}{ CIPW norms (weight percent) } \\
\hline Quartz & 32.32 & 34.18 & 32.46 & 29.09 & 26.45 & 28.77 & 25.60 & 27.33 & 26.48 & 42.72 & 35.55 & 37.65 & 30.73 & 32.03 & 32.44 & 33.11 & 30.28 & 38.29 & 36.05 & 36.39 & 32.19 & 30.85 \\
\hline Corundum & 0.76 & 3.03 & 1.89 & 1.21 & 0.74 & 0.53 & 0.93 & 0.92 & 0.79 & 2.84 & 0.85 & 1.34 & 0.65 & 1.20 & 0.88 & 1.22 & 1.57 & 1.37 & 1.18 & 1.19 & 2.30 & 2.36 \\
\hline Orthoclase & 23.81 & 28.28 & 23.03 & 25.00 & 23.05 & 24.65 & 25.75 & 25.78 & 25.65 & 50.82 & 30.89 & 29.28 & 30.51 & 36.02 & 29.11 & 33.01 & 32.31 & 29.76 & 31.90 & 24.46 & 28.67 & 32.16 \\
\hline Albite & 27.29 & 26.34 & 22.84 & 32.09 & 23.46 & 23.50 & 22.67 & 21.63 & 21.95 & 1.63 & 25.89 & 24.01 & 26.14 & 21.92 & 25.64 & 22.74 & 23.93 & 29.92 & 23.34 & 23.30 & 22.20 & 24.90 \\
\hline Anorthite & 10.80 & 4.80 & 12.44 & 8.72 & 16.41 & 14.06 & 14.97 & 14.41 & 14.95 & 0.00 & 2.72 & 3.22 & 5.67 & 3.67 & 5.57 & 5.09 & 5.32 & 2.51 & 3.52 & 11.60 & 6.79 & 6.37 \\
\hline Hyperthene & 3.74 & 2.24 & 5.32 & 2.83 & 7.48 & 7.34 & 6.91 & 7.54 & 7.77 & 1.15 & 2.63 & 2.99 & 4.58 & 3.14 & 4.28 & 3.26 & 4.62 & 2.30 & 2.39 & 2.46 & 5.87 & 2.52 \\
\hline Magnetite & 0.60 & 0.39 & 0.94 & 0.49 & 1.17 & 0.10 & 1.07 & 1.11 & 1.14 & 0.28 & 0.79 & 0.74 & 0.68 & 0.96 & 1.00 & 0.67 & 0.82 & 1.01 & 0.95 & 0.29 & 0.70 & 0.41 \\
\hline Ilmenite & 0.54 & 0.37 & 0.78 & 0.41 & 0.96 & 0.86 & 0.84 & 0.93 & 0.94 & 0.42 & 0.54 & 0.63 & 0.85 & 0.74 & 0.85 & 0.67 & 0.83 & 0.58 & 0.49 & 0.17 & 0.89 & 0.27 \\
\hline Apatite & 0.14 & 0.37 & 0.30 & 0.16 & 0.28 & 0.19 & 0.26 & 0.35 & 0.33 & 0.30 & 0.14 & 0.14 & 0.19 & 0.32 & 0.23 & 0.23 & 0.32 & 0.32 & 0.18 & 0.14 & 0.39 & 0.16 \\
\hline
\end{tabular}

Analyses by Alaska Division of Geological \& Geophysical Surveys laboratory using X-ray fluorescence methods. 